\title{
Household behaviour in installing property-level flood adaptations: a literature review
}

\author{
G. Everett \& J. Lamond \\ Department of Architecture and the Built Environment, \\ University of the West of England (UWE), UK
}

\begin{abstract}
The research presents a brief overview of the published literature concerning household behaviour with regard to installing flood protection measures in the UK; people's desire and their ability to act are considered, before looking at the literature around public perceptions of arguably more sustainable, 'blue-green' approaches to flood-risk management. Interesting contrasts are found in these two different forms of adaptations to address flood risk ('structural' and 'sustainable'); however it is demonstrated that a paucity of research exists in this area, particularly around medium- to longer-term behavioural adaptations to sustainable approaches, and so suggestions are made for further research to help develop our understanding.

Keywords: floods, flood risk management (FRM), sustainable drainage systems (SuDS), sustainable, blue-green, knowledge co-construction.
\end{abstract}

\section{Introduction}

Despite the fact that around 5.5 million properties are situated in areas at risk of flooding from rivers, the sea and surface water in England and Wales (Environment Agency [1, 2]), installation of flood protection measures by UK households and businesses remains low; around $27 \%$ for households that have previously experienced flooding and only $6 \%$ for those that have not (Thurston et al. [3], Harries [4, 5]). This lack of action is a matter of concern for authorities such as the Department for Environment, Food and Rural Affairs (Defra) and the Environment Agency (EA), especially considering that with climate change, some are forecasting that UK flooding could increase up to 30 times over the 
next 75 years, costing tens of billions of pounds every year (King [6], cf. Whitmarsh [7]).

This paper will present a literature review of household and business behaviour with regard to installing flood protection, with a view to deriving hypotheses about how this behaviour might change with different approaches to flood-risk management (FRM), arguing the need for more research around public perceptions of sustainable 'blue-green' FRM. Households and businesses have been chosen for this study as one central and significant 'stakeholder' at the frontline of flood experience, those who should have the greatest incentives to take action but who may face a series of barriers.

If households are to take action to protect against flooding, they will need to engage in a number of stages of thinking and overcome a variety of barriers. Lamond and Proverbs [8] usefully frame these as Desire (awareness, perception, ownership) and Ability (knowledge, finance, belief) and provide a comprehensive literature review of barriers (and incentives) to action. The first section of this paper will consider literature around Desire or behaviour framing, the prerequisites for action and the conditions affecting likelihood of action. Secondly the paper will look at literature around flood protection action or Ability. It will then look at what has been written around public perspectives upon alternative approaches to FRM such as Sustainable Drainage Systems (SuDS). This work will contribute to the development of a conceptual model of public behaviour regarding more sustainable FRM infrastructure.

\section{Desire: awareness, understanding, acceptance and ownership}

Households must be aware of the possibility of flooding if they are to take action. This awareness is not nearly as widespread as might be hoped (Ludy and Kondolf [9]; Kelman [10]; Bhattacharya et al. [11]; Kreibich et al. [12]); raising awareness was a key issue highlighted in the Pitt Review [13] of the 2007 UK floods. With up to two-fifths of people in flood-risk areas unaware of the threat (Burningham et al. [14]), the general conclusion is that awareness-raising remains a necessary first, but by no means sufficient, step for behaviour-change (Young and O’Neill [15]; Fielding et al. [16]; Defra [17]).

Beyond being aware of the risk of flooding, it is centrally important that people understand the way this risk is communicated. Research has found that many people misunderstand a $1 / 100$ or $1 \%$ flood risk as meaning that after a flood there will assuredly be a long period before the next incidence [9, 15] (cf. Brilly and Polič [18]; O’Sullivan et al. [19]; Tinker and Galloway [20]; Bell and Tobin [21]), although percentages are better understood than frequencies (Baan and Klijn [22]). Research has therefore stressed the need to speak of severity and impact as well as frequency in order to clarify risk communication (Bell [23]). However too much focus solely on awareness could disempower people and encourage fatalism, refusal and blind hope (Bubeck et al. [24], cf. Grothmann and Reusswig [25]). This has led writers such as Richardson et al. [26] to argue that awareness-raising works best alongside community 
resilience strengthening and advice about protection measures (cf. Bradford et al. [27]).

Once people are properly aware of and understand the risks of flooding, the next step towards their taking protective measures is acceptance. A key trait that emerges from the literature concerning stakeholder behaviour however is refusal or denial, and a good amount of research has been conducted around this (Defra [28]; Speller [29]; [cf. 14, 18, 24, 25, 27]). This denial can be due to what Harries [30] terms preserving their ontological over their physical security, preferring to feel secure rather than taking action to increase actual physical security and thereafter being reminded of the risk by the measures in place (cf. [14]; Soane et al. [31]; Whittle et al. [32]; Defra [33]; Lamond et al. [34]).

There is also an understandable issue around relationships of trust between communities and authorities (Motoyoshi [35]; Gotch et al. [36]; Tapsell and Tunstall [37]). Communities may not be happy to accept labelling from above or outside for fear that it will blight properties [14], and will have local knowledge that may have not been accounted for (White and Richards [38]; McEwen and Jones [39]). A growing number of authors, including Defra and the EA, have thus advocated a knowledge co-construction approach where all sides discuss and learn from each other, over a 'deficit model', expert-public knowledgetransfer approach ([16, 38]; Thrush et al. [40]; Evers et al. [41]; cf. [14, 19]).

Many have identified prior experience as one of the most influential factors in raising flood hazard perception and so concern (Werritty et al. [42]; Burn [43]; Siegrist and Gutscher [44]; Correia et al. [45]; cf. [9, 14, 18, 38]); intention to take adaptive action has been found to be stronger in those who have experienced flooding (Kreibich et al. [12, 46]). McEwan et al. [39, 47] and Correia et al. [45] both separately argue for the accumulation of oral narratives to embed flood experiences over time. 'Flood memory' is key to developing awareness and acceptance of flood risk, but lessons learned from flooding can fade over time as household memories become more distant and populations change.

Once people understand the risks faced, they must 'own' them if they are to take protective measures. Without a responsibility to mitigate the problem, people may remain passive (Ludy and Kondolf [9]; Wedawatta et al. [48]) and expect government or insurance to cover costs [18]. For this reason the EA and Defra have prioritised 'responsibility' in community engagement (Speller [29]; Defra [49]; Twigger-Ross [50]). Some have argued that households and businesses do not take ownership of the issue [42, 45], whilst others have contended that they recognise at least joint responsibility with authorities (Laska [51]). Kazmierczak and Bichard's [52] research found that the median sum people were willing to pay was a one-off of less than $£ 100$, indicating ownership problems since this would be significantly less than the cost of effective measures.

Taking ownership of flood-risk can be a very emotional process; it is argued that many people tend rather to rely on government to act and insurers to provide compensation [8, 42] (cf. Defra [53]). Some have argued that government compensation following flooding negatively influences households' willingness 
to install flood protection and buy insurance (Botzen et al. [54]; Bubeck et al. [24], Grothmann and Reusswig [25]); Botzen's results also showed homeowners would install flood protection to gain insurance premium reductions, pointing to opportunities for incentivising action.

With regard to businesses, the same barriers and stages of awareness will apply. Wedawatta [48] has conducted an impressive literature review of business responses to flooding which found that a majority of businesses are not concerned about flooding and have no continuity plan in place, with only 8\% having signed up for flood warnings (cf. Bhattacharya et al. [11]; Crichton [55]). A survey of England for the EA found only 25\% of businesses had an emergency plan for flooding events, with $32 \%$ believing flooding would not interrupt activities [3]. The size of businesses and their experiences with flooding will understandably have some effect upon this, but international research has found that many do not implement flood protection even after being flooded (Molino and Gissing [56]). Kreibich et al. [12] also noted a better response to installing flood protection from households than businesses following the 2002 floods in Germany, suggesting further work is needed to understand incentives and barriers in this area.

\section{Acting: knowledge, finance, aesthetics and context, belief}

Assuming that these hurdles are overcome, the published research demonstrates that households and businesses may face a second layer of difficulties that must be overcome; four further major barriers have been extensively written about that fall under the Acting banner. Once people have taken ownership of flood risk, the next issue is whether they have a proper understanding of flood protection measures. There is argued to be poor awareness of these in England and Wales, with roughly $80 \%$ of people in one study unable to name anything other than sandbags for protection, and only 10\% knowing of any flood resilience technique [33]. Sandbags are still the principal public understanding of flood resistance in the UK [3, 11], and were the primary attempted means of defence in the 2000 floods (Proverbs and Lamond [57]). Sandbags were found by Botzen et al. [54], cf. [24] to be a preferred flood protection device, with $68 \%$ of respondents saying they would buy them, whilst more resilient measures (such as replacing floors with tiles and moving boilers) received only 20-25\% agreement.

Harries [5] found that many people see household-level protection measures as but a stop-gap prior to the establishment of structural work, or even as 'covering up' the problems faced but providing no real solution to more major floods (cf. [46]). This lack of confidence in household protection measures will inevitably impact take-up. Similarly barriers occur with people's confidence in flood resilience measures over resistance ones. Interest in resilient measures improved after a programme of action in England, but intention to act did not show the same improvements due to aesthetic and property value concerns [53].

As previously mentioned, homeowners and communities may be unwilling to accept the branding of flood-risk, and so reluctant to install protection measures. This can be due to a fear that the visibility of measures will mark properties as at 
flood risk and impact upon property value [5, 14, 53, 57]. Aesthetic concerns can also be an issue, both for present standard of living and fear that lessened aesthetics again may impact upon property value [54] (cf. Consumer Council [58]). Some however have argued that measures can be quite aesthetically acceptable (Bowker [59]), and SuDS like ponds have been praised for their aesthetic value (Jones and Macdonald [60]; Kazmierczak and Connelly [61]). There may thirdly be pressure to conform to community standards; if flood protection is not the norm, it could be difficult to go against the grain [4, 52], especially as this is seen as advertising risks others would prefer to be ignored.

The perceived cost of protections are a major factor for those considering them (Siegrist and Gutscher [62]). However Harries [4] has argued that we place too much weight on the influence of risks, costs and benefits. His research found no correlation between these and people's actions, contending that insecurities and anxieties were more dominant. Anxieties could be about future flooding, but anxieties caused by protection measures' constant reminder of possible future flooding also showed strongly. Bubeck et al.'s [24] literature review found perception of risk less significant than 'threat appraisal' and 'coping appraisal': perceptions of the probability and consequences of flooding, the efficacy and cost of protection measures and people's ability to install them. Home ownership is a matter requiring further research, some finding it to be a significant factor affecting protection [25, 46], others only a small to medium-sized factor [24] and yet others of no statistical significance (Clark and Priest [63]). In a project conducted for Defra, Harries [5] found households more willing to take up flood protection when funded by a government grant; $83 \%$ of 240 households across 6 sample sites took up the opportunity, whereas in an earlier study only $39 \%$ installed measures following flooding (even though the measures made people feel only slightly safer, not being considered sufficient). Harries also noted, however, that state-funded work confirmed beliefs that protection was a state duty rather than a personal responsibility.

As mentioned, Bubeck et al. [24] and Grothmann and Reusswig [25] argue that people's “coping appraisal” is fundamental, as those who believe nothing can be done may tend towards wishful thinking, helplessness, fatalism or despair. Providing specific, local, practical guidance can help people move beyond helplessness [27], whilst allowing communities to express concerns and local knowledge can ensure guidance is appropriate and effective. Belief in the effectiveness of measures is a matter of knowledge co-construction and consensus development, with economic analysis for estimated costs and projected savings. For example, Kreibich et al. [12] found that after the 2002 floods in Germany, two out of a chosen (for the study) six household protection measures had reduced damage ratios by around 50\%. Thurston et al. [3] found that in the UK, resistance measures are worthwhile for households that have a $2 \%$ chance of flooding, and that temporary resistance measures can reduce damage by $50 \%$. 


\section{What do people think of 'Blue-Green' FRM approaches?}

UK policy now favours more sustainable FRM (Defra [17]; Scottish Government [64]). This approach includes Sustainable Drainage Systems (SuDS), 'a catch-all term for a number of different systems', a shift in the means by which water is 'disciplined' [60], from water-butts, permeable paving and green roofs to wetlands, ponds and swales, to slow, filter or retain water run-off, putting it to productive use near where it lands rather than seeking to disperse it quickly. This shift in thinking will of course require the involvement of all stakeholders, including affected publics, in the development of new approaches, which raises a series of questions about where public preferences currently lie, and how they might change over time with the adoption of 'blue-green' approaches.

A number of authors have asserted that the public still prefer structural flood defences. Werritty et al. [42] found structural defences supported by over $90 \%$ of their respondents, with SuDS low down the list; Johnson and Priest [65] looked to the benefits of sustainable approaches but concluded that the insurance industry, public and media all remained 'heavily focused' on structural defences. In contrast, Kenyon [66] found general public preferences for more 'blue-green' solutions, with structural defences being the least favoured option. Similarly overall, Apostolaki and Jefferies [67] found that the public they surveyed preferred softer, more sustainable approaches. Attitudes to ponds and managed rivers were positive simply because of their amenity, recreation and aesthetic benefits. Awareness of SuDS' flood functions were argued to be very low, with most respondents unaware of the term or their contributions to flood-control. It was observed that people's views about SuDS related to their awareness of the functions and services provided, from flood-control through improved amenities, recreation facilities and biodiversity. Their overriding message was therefore that education and consultation will be vital to building understanding whereby sustainable strategies can be pursued, appreciated, managed and maintained.

More recently, Bastien et al. [68] found that public awareness of ponds' functions as SuDS was much higher than in Apostolaki's research, with almost 3 in 4 people surveyed understanding this function. As with Apostolaki, Bastien et al. emphasised education was key, since pond safety was a major public concern and a large difference existed between perceived and actual safety levels (cf. McKissock et al. [69]). Another major concern with ponds found by both authors was 'pollution', namely litter. Only a small amount of litter was felt to interfere with a pond's aesthetic amenities, highlighting the need for good maintenance regimes. Bastien et al. found that willingness to pay for pond amenities could, if factored in and charged for correctly, offset construction and maintenance costs. Relatedly, Wright et al. [70] have researched 'urban creep' (house extensions, concreting over gardens, adding hard-standing), finding a gradual reduction in urban drainage provision; although only $2 \%$ of households surveyed had any plans to convert driveways back into gardens, a majority supported more widespread use of SuDS, indicating support for blue-green solutions. 
We noted above that many people do not want to spend on structural flood protection for their own households, and so could therefore hypothesise that in the first instance they would not volunteer to pay for household-level blue-green solutions, nor for solutions to protect against others' flood risk. These might therefore need to become a collective, or authority responsibility. Larger-scale sustainable approaches (like ponds and swales) may also need to be implemented at a community level; we could similarly hypothesise that the community nature of such protection might strengthen convictions that authorities should be responsible for costs. Community members might also not in the first instance want taxes used to pay for such endeavours, because of preferences for structural defences. Consultations with public groups could be undertaken in discussing viable options and developing most preferred solutions, with schemes then developed by relevant authorities, removing the felt responsibility and fear of blame noted above. Some of the works cited above however indicate how people value ponds for their aesthetic, amenity, recreation and biodiversity functions. This is encouraging in indicating a potential willingness to pay for these services. The value people attribute to these functions could be enhanced by awarenessraising exercises, and by exposure to these new solutions over time as habits and practices shift to accommodate them.

It is clear that further research is needed in this area to understand more about people's thinking around the costs and benefits of structural and sustainable FRM approaches, and how this thinking could change over time as these approaches become normalised and lifestyles and practices alter. A next useful step would be the development of a conceptual model for analysing public perceptions of, and behaviour concerning, sustainable FRM. One way this could possibly then be developed would be stated preference work with sample populations. Longer-term sociological studies of people and groups, observing behaviour (and changes in behaviour over time) and expressed preferences and dis/satisfactions with their environment and proposed means of managing food risk could also be helpful. Work with communities will be necessary to understand how the multiple variables at play might settle in terms of dis/favouring different FRM options over time and under a variety of hypothetical situations; and how these preferences might develop and change as blue-green approaches develop and people become more accustomed to them. It would be important to conduct this work with all stakeholder groups who could be affected by the adoption of 'blue-green' FRM, including those not directly at flood risk. The possibilities of de/gentrification of areas and the outcomes of flood events should also be considered, as should any wider benefits and costs suggested by participants.

\section{Conclusion}

In this brief review we have seen that the UK take-up of household flood defences remains very low, whilst flooding looks set to increase with climate change, and that this is a matter of concern for government and other stakeholders. The barriers holding households back from taking action were 
presented in Sections One and Two, developing the desire to take action and the ability to act. Section Three looked at how thinking is shifting towards more sustainable FRM and surveyed the published literature upon how households might react to this. It was concluded that there exists a paucity of research with often quite contradictory findings, indicating that more research is needed in this area.

Between Werritty, Apostolaki and Jefferies and Kenyon we are given three quite primary-colour understandings of public FRM preferences and more nuance would help in thinking through satisfactory solutions; we currently understand very little about public FRM preferences. Bastien et al.'s work indicates potential willingness to pay for SuDS ponds for their wider functions aside from FRM. The next step will be to investigate public preferences more closely and develop models of behaviour over time based on these, to develop a deeper understanding of how people might react to changing blue-green solutions (as biodiversity increases and aesthetics improve). This in turn would help us understand how different FRM approaches might perform as perceptions and behaviour change.

\section{References}

[1] Environment Agency, Flooding in England: A National Assessment of Flood Risk, Environment Agency: Bristol, 2009.

[2] Environment Agency, Flooding in Wales: A National Assessment of Flood Risk, Environment Agency: Bristol, 2009.

[3] Thurston, N., Finlinson, B. and Breakspear, R., Developing the Evidence Base for Flood Resistance and Resilience: Summary Report, Environment Agency: Bristol, 2008.

[4] Harries, T., The anticipated emotional consequences of adaptive behavior impacts on the take-up of household flood-protection measures. Environmental Planning A, 44(3), pp. 649-668, 2012.

[5] Harries, T., Household Flood Protection Grants: The householder perspective. Defra and Environment Agency Flood and Coastal Risk Management Conference, 2010.

[6] King, D.A., Climate change science: adapt, mitigate, or ignore? Science, 303(5655), pp. 176-177, 2004.

[7] Whitmarsh, L., Are flood victims more concerned about climate change than other people? The role of direct experience in risk perception and behavioural response. Journal of Risk Research, 11(3), pp. 351-374, 2008.

[8] Lamond, J.E. and Proverbs, D.G., Resilience to flooding: lessons from international comparison. Urban Design and Planning, 162(2), pp. 63-70, 2009.

[9] Ludy, J. and Kondolf, G.M., Flood risk perception in lands “protected” by 100-year levees. Natural hazards, 61(2), pp. 829-842, 2012.

[10] Kelman, I., Floods should not mean disasters. Building Research and Information, 33(3), pp. 287-292, 2005. 
[11] Bhattacharya, N., Lamond, J. and Proverbs, D., Flood Vulnerability and Hazard Adjustment of UK commercial sector: A synthesis of Research. International Conference on Building Resilience, 2011.

[12] Kreibich, H., Seifert, I., Thieken, A.H., Lindquist, E., Wagner, K. and Merz, B., Recent changes in flood preparedness of private households and businesses in Germany. Regional Environmental Change, 11(1), pp. 59-71, 2011.

[13] Pitt, M., Learning Lessons from the 2007 Floods: An Independent Review, Cabinet Office: London, 2008.

[14] Burningham, K., Fielding, J. and Thrush, D., "It'll never happen to me": understanding public awareness of local flood risk. Disasters, 32(2), pp. 216-238, 2008.

[15] Young, J. and O'Neill, P., A social marketing framework for the development of effective public awareness programs. New South Wales State Emergency Services, 1999.

[16] Fielding, J., Burningham, K. and Thrush, D., Public response to flood warning. Environment Agency: Bristol, 2007.

[17] Defra, Making Space for Water: Taking forward a new Government strategy for flood and coastal erosion risk management in England. Defra: London, 2005.

[18] Brilly, M. and Polič, M., Public perception of flood risks, flood forecasting and mitigation. Natural Hazards and Earth System Sciences, 5, pp. 345355, 2005.

[19] O’Sullivan, J.J., Bradford, R.A., Bonaiuto, M., Dominicis, S. De., Rotko, P., Aaltonen, J., Waylen, K. and Langen, S.J., Enhancing flood resilience through improved risk communications. Natural Hazards and Earth System Sciences, 12, pp. 2271-2282, 2012.

[20] Tinker, T. and Galloway, G.E., How Do You Effectively Communicate Flood Risks? Looking to the Future. Booze Allen Hamilton: London, 2008.

[21] Bell, H. and Tobin, G.A., Efficient and effective? The 100-year flood in the communication and perception of flood risk. Environmental Hazards, 7(4), pp. 302-311, 2007.

[22] Baan, P.J.A. and Klijn, F., Flood risk perception and implications for flood risk management in the Netherlands. International Journal of River Basin Management, 2(2), pp.113-122, 2004.

[23] Bell, H., Efficient and effective? The hundred year flood in the communication and perception of flood risk. Environmental Hazards, 7, pp. 302-311.

[24] Bubeck, P., Botzen, W.J.W. and Aerts, J.C.J.H., A Review of Risk Perceptions and Other Factors that Influence Flood Mitigation Behavior. Risk Analysis, 32(9), pp. 1481-1495, 2012.

[25] Grothmann, T. and Reusswig, F., People at Risk of Flooding: Why Some Residents Take Precautionary Action While Others Do Not. Natural hazards, 38(1-2), pp. 101-120, 2006. 
[26] Richardson, J. Reilly, J. and Jones, P., Community and public participation: risk communication and improving decision making in flood and coastal defence. Defra Flood and Coastal Management Conference, 2003.

[27] Bradford, R.A., O’Sullivan, J.J., van der Craats, I.M., Krywkow, J., Rotko, P., Aaltonen, J., Bonaiuto, M., Dominicis, S.De, Waylen, K. and Schelfaut, K., Risk perception - issues for flood management in Europe. Natural Hazards and Earth System Sciences, 12, pp. 2299-2309, 2012.

[28] Defra, Flood risk and insurance: A roadmap to 2013 and beyond. Defra: London, 2011.

[29] Speller, G., Improving community and citizen engagement in flood risk management decision making, delivery and flood response. Environment Agency: Bristol, 2005.

[30] Harries, T. Feeling secure or being secure? Why it can seem better not to protect yourself against a natural hazard. Health, Risk and Society, 10, pp. 479-490, 2008.

[31] Soane, E., Schubert, I., Challenor, P., Lunn, R., Narendran, S. and Pollard, S., Flood perception and mitigation: the role of severity, agency, and experience in purchase of flood protection, and the communication of flood information. Environment and Planning A, 42(12), pp. 3023-3038, 2010.

[32] Whittle, R. Medd, W., Deeming, H., Kashefi, E., Mort, M., Twigger Ross, C., Walker, G. and Watson, N., After the rain-learning the lessons from flood recovery in Hull. Final project report for Flood, Vulnerability and Urban Resilience: a real-time study of local recovery following the floods of June 2007 in Hull, 2010.

[33] Defra, Consultation on policy options for promoting property-level flood protection and resilience, Defra: London, 2008a.

[34] Lamond, J., Dhonau, M., Rose, C. and Proverbs, D., Overcoming the barriers to installing property level flood protection: An overview of successful case studies. Road Map Towards a Flood Resilient Urban Environment, eds. E. Pasche, N. Evelpidou, C. Zevenbergen, R. Ashley and S. Garvin, Urban Flood Management Cost Action Network C22: Paris, 2009.

[35] Motoyoshi, T., Public perception of flood risk and community-based disaster preparedness. A better integrated management of disaster risks, eds. S. Ikeda, T. Fukuzono, and T. Sato, Terrapub: Tokyo, pp. 121-134.

[36] Gotch, C., Risk, G.B. and Council, R.A., Rising levels? Public awareness and understanding of risks from flooding, Risk and Regulation Advisory Council: London, 2013.

[37] Tapsell, S.M. and Tunstall, S.M., "I wish I'd never heard of Banbury”: The relationship between 'place' and the health impacts from flooding. Health and Place, 14(2), pp. 133-154, 2008.

[38] White, I. and Richards, J., Stakeholder and community engagement in flood risk management and the role of AAPs. Flood Risk Management Research Consortium, July, University of Manchester, Manchester, 2008.

[39] McEwen, L.J. and Jones, O., The role of local/lay flood knowledge in building community resilience: the case of the 2007 floods, 
Gloucestershire, UK. British Hydrological Society Third International Conference, Online: British Hydrological Society, 2010.

[40] Thrush, D., Burningham, K. and Fielding, J., Flood Warning for Vulnerable Groups: A review of literature, Environment Agency: Bristol, 2005.

[41] Evers, M., Jonoski, A., Maksimovic, C., Lange, L., Ochoa Rodriguez, S., Teklesadik, A., Cortes Arevalo, J., Almoradie, A., Eduardo Simoes, N. Wang, L. and Makropoulos, C., Collaborative modelling for active involvement of stakeholders in urban flood risk management. Natural Hazards and Earth System Sciences, 12(9), pp. 2821-2842, 2012.

[42] Werritty, A., Houston, D. and Ball, T., Exploring the Social Impacts of Flood Risk and Flooding in Scotland, Scottish Executive Social Research: Edinburgh, 2007.

[43] Burn, D.H., Perceptions of flood risk: A case study of the Red River Flood of 1997. Water Resources Research, 35(11), pp. 3451-3458, 2010.

[44] Siegrist, M. and Gutscher, H., Flooding Risks: A Comparison of Lay People's Perceptions and Experts' Assessments in Switzerland. Risk Analysis, 26(4), pp. 971-979, 2006.

[45] Correia, F.N., Fordham, M., Da Graca Saraiva, M., Bernardo, F., Flood hazard assessment and management: interface with the public. Water Resources Management, 12(3), pp. 209-227, 1998.

[46] Kreibich, H., Thieken, A.H., Petrow, T., Muller, M. and Merz, B., Flood loss reduction of private households due to building precautionary measures - lessons learned from the Elbe flood in August 2002. Natural Hazards and Earth System Science, 5(1), pp. 117-126, 2005.

[47] McEwen, L., Krause, F., Hanson, J. and Jones, O., Flood histories, flood memories and informal flood knowledge in the development of community resilience to flood risk. BHS 11th National Hydrology Symposium, 2012.

[48] Wedawatta, G.S.D., Ingirige, M. and Proverbs, D., Adaptation to flood risk: the case of businesses in the UK. International Conference on Building Resilience, 2011.

[49] Defra, Annex B: Flood Community Resilience Scheme Projects Funded By Defra, Defra: London, 2013.

[50] Twigger-Ross, C., Managing the Social Aspects of Flooding: Synthesis Report, Environment Agency: Bristol, 2005.

[51] Laska, S.B., Involving Homeowners in Flood Mitigation. Journal of the American Planning Association, 52(4), pp. 452-466, 1986.

[52] Kazmierczak, A. and Bichard, E., Investigating homeowners' interest in property-level flood protection. International Journal of Disaster Resilience in the Built Environment, 1(2), pp.157-172, 2010.

[53] Defra, Resilience Grants Pilot Projects, Defra: London, 2008b.

[54] Botzen, W.J.W., Aerts, J.C.J.H. and van den Bergh, J.C.J.M., Willingness of homeowners to mitigate climate risk through insurance. Ecological Economics, 68(8-9), pp. 2265-2277, 2009.

[55] Crichton, D., Climate Change and Its Effects on Small Businesses in the UK, AXA Insurance: Cardiff, 2006. 
[56] Molino, S. and Gissing, A., Lessons From The Past Are Not Always Used: Business Flood Preparedness in Two NSW Communities. 45th Annual Conference of the NSW Floodplain Management Authorities, 2005.

[57] Proverbs, D. and Lamond, J., The Barriers to Resilient Reinstatement of Flood Damaged Homes. 4th International i-Rec Conference, 2008.

[58] Consumer Council, Research Paper on Flood Protection and Insurance, National Consumer Council: London, pp. 1-29, 2013.

[59] Bowker, P., Flood Resistance and Resilience Solutions: An R and D Scoping Study, Defra: London, 2007.

[60] Jones, P. and Macdonald, N., Making space for unruly water: sustainable drainage systems and the disciplining of surface runoff. Geoforum, 38(3), pp. 534-544, 2007.

[61] Kazmierczak, A. and Connelly, A., Buildings and Flooding: A RiskResponse Case Study, University of Manchester: Manchester, 2011.

[62] Siegrist, M. and Gutscher, H., Natural Hazards and Motivation for Mitigation Behavior: People Cannot Predict the Affect Evoked by a Severe Flood. Risk Analysis, 28(3), pp. 771-778, 2008.

[63] Clark, M.J. and Priest, S.J., Public Awareness of Flood Risk: The Role of the Environment Agency Flood Map Research Report. ESRC End of Award Report, RES-000-22-1710. ESRC: Swindon, 2008.

[64] The Scottish Government, The Water Environment and Water Services (Scotland) Act 2003 (Commencement No. 8) Order 2008, The Scottish Government: Edinburgh, 2003.

[65] Johnson, C.L. and Priest, S.J., Flood Risk Management in England: A Changing Landscape of Risk Responsibility? International Journal of Water Resources Development, 24(4), pp. 513-525, 2008.

[66] Kenyon, W., Evaluating flood risk management options in Scotland: A participant-led multi-criteria approach. Ecological Economics, 64(1), pp. 70-81, 2007.

[67] Apostolaki, S. and Jefferies, C., Social impacts of stormwater management techniques including river management and SUDS. Final report, SUDS01. Environment Agency: Bristol, 2005

[68] Bastien, N.R.P., Arthur, S. and McLoughlin, M.J., Valuing amenity: public perceptions of sustainable drainage systems ponds. Water and Environment Journal, 26(1), pp. 19-29, 2011.

[69] McKissock, G., Jefferies, C. and D’Arcy, B.J., An assessment of drainage best management practices in Scotland. Water and Environment Journal, 13(1), pp. 47-51, 1999.

[70] Wright, G.B. Arthur, S., Bowles, G., and Bastien, N. and Unwin, D., Urban creep in Scotland: stakeholder perceptions, quantification and cost implications of permeable solutions. Water and Environment Journal, 25(4), pp. 513-521, 2011. 